\title{
Wood Loss Assessment in Forest of Sal (Shorea robusta) by Heart Rot of Central Terai of Nepal
}

\author{
Shankar Tripathi $(1)$ and Yojana Adhikari 10 \\ Agriculture and Forestry University, Bharatpur, Nepal \\ Correspondence should be addressed to Shankar Tripathi; stripathi@afu.edu.np
}

Received 23 November 2020; Revised 15 March 2021; Accepted 23 March 2021; Published 2 April 2021

Academic Editor: Steve Chhin

Copyright ( 2021 Shankar Tripathi and Yojana Adhikari. This is an open access article distributed under the Creative Commons Attribution License, which permits unrestricted use, distribution, and reproduction in any medium, provided the original work is properly cited.

\begin{abstract}
A significant volume of wood was lost due to wood defects; however, few studies were done to quantify wood loss by wood defects. This study was focused on quantifying wood loss by heart rot, especially hollowness in Shorea robusta. The study was conducted in Tileswornath community forest of Rautahat district. The data were collected from the felling site of the regeneration felling block of Tileswornath community forest. 44 trees were selected randomly, and tree diameter, total height, and volume were measured. The destructive method was followed as heart rot cannot be visible from the surface. Felled trees were sanctioned into 285 logs and separated based on the hollowness. Hollow diameters at both thin end and mid and thick end, as well as length, were measured on the hollow log, and Smalian's formula was used to calculate the volume of hollowed portion, and volume calculation formula for the cylinder was used to calculate total volume. For the solid logs, mid diameter and length of the log were measured and volume calculation formula for the cylinder was used to calculate total volume. Logistic regression was performed to identify the relation of total height and diameter with the probability of hollowness presence. The study showed that 59\% of sampled trees and $34.39 \%$ of logs were found to be hollowed due to heart rot. $41.79 \%$ volume was occupied by hollow on the hollowed log. Logistic regression discards the relation of height to the hollowness but signified the relation of diameter to the probability of hollowness presence. Before implementation of scientific forest management modality, the timber retained in stump per tree was found as 0.18 cubic feet.
\end{abstract}

\section{Introduction}

Wood decay is the biological process that converts lignin and cellulose to carbon dioxide and water [1]. Wood decay in the living trees is a major disease-causing loss of wood products and product quality $[1,2]$. Wound is the major factor for starting wood decay in living trees. Large animals, birds, insects, and bark beetles are responsible for making wounds on the bark and sapwood portion and the wound is infected by wood decay pathogen [3]. Wood rotting fungi prefer heartwood, and the tree grows and adds new wood, while live sapwood compartmentalizes infected wood by active protective processes. Although heart rot and cavities were beneficial for wildlife management, it is problematic for the forest which is managed for the timber production [4]. Nepal has almost $45 \%$ of its area as forested areas, and these forested areas are managed by different approaches, that is, Government Managed Forest, Leasehold Forest, Community Forest, Religious Forest, Collaborative Forest, Protected Forest, Protected Area, and Private Forest. Beside some regime of protected area and protected forest, all other forests were used to fulfil the local and national demand of different forest product. Due to the conservation based passive forest management system, the demand of timber was not fulfilled by the forest. So Scientific Forest Management (hereafter ScFM) is introduced to manage forest actively and produce high volume of timber. ScFM is basically silvicultural based forest management system and irregular shelterwood system was preferred and used to manage the forest in Nepal. It was implemented with two principles, that is, to remove the overmature tree from the forest and to enhance the regeneration. 
The practice of ScFM involves harvesting mature forests. As the primary aim of ScFM was to increase the production and meet the demand for timber, ScFM primarily is implemented on high-value timber forests. Among the important timber species, Shorea robusta dominates more than half of the lowland forests of Nepal [5]. According to a study in [6], Shorea robusta is highly valuable and is the most popular timber species for building construction (such as door and window frames) and other commercial purposes. Shorea robusta is mostly found in national forests such as government-managed forests, community forests, and collaborative forests [7].

During the harvesting of Shorea robusta tree, most of the tree was found to be defected, where the huge amount of timber was valueless [8]. Most of the trees were found to be hollow on the stem. A tree hollow or tree hole is a semienclosed cavity that has naturally formed in the trunk or branch of a tree. Hollows form in many species of trees and are a prominent feature of natural forests and woodlands. Hollows may form as a result of physiological stress from natural forces causing the excavation and exposure of the heartwood. Forces include wind, fire, heat, lightning, rain, attack from insects (such as ants or beetles), bacteria, and fungi. Also, trees may self-prune, dropping lower branches as they reach maturity, exposing the area where the branch was attached [9]. The probability of a tree containing hollows and the number of hollows have been associated with several factors. These include tree diameter, tree form, tree species, and presence of fire scar, tree age, and so forth [10]. Hymenochaete rubiginosa, Fomes caryophylli, and Fomes fastuosus are the major heart rot causing agents in the Shorea robusta. Hymenochaete rubiginosa attacks through wounds caused by fire and wood loss accounting for approximately $50 \%$ of the wood decay due to all-cause in Shorea robusta [11].

In Nepal, very few studies were conducted on the loss assessment of timber due to different agents; and this study is one of the pioneer researches on these tree defects found in Shorea robusta and the amount of loss due to this defect. This study assesses the amount of volume loss due to defect in the ScFM which ultimately emphasized the importance of ScFM as it is able to timely remove the defected trees from the forest.

\section{Materials and Methods}

2.1. Study Area. The study was carried out in Tileswornath community forest (CF) of Rautahat district which lies under province 2 of Nepal (Figure 1). The east boundary of the CF is Chandikhola, west is Alajorkhola, north is Namobuddha CF, and south is Vorleni CF. Tileswornath CF covers a total area of $219.6 \mathrm{ha}$. It is situated in between $27^{\circ} 942^{\prime \prime}$ from $27^{\circ} 11^{\prime} 7^{\prime \prime}$ north latitude and $85^{\circ} 19^{\prime} 13^{\prime \prime}$ from $85^{\circ} 20^{\prime} 16^{\prime \prime}$ east longitude with elevation of $160 \mathrm{~m}$ to $200 \mathrm{~m}$. Major tree species here are Shorea robusta, Terminalia alata, Syzygium cumini, Bombax ceiba, T. bellirica, Acacia catechu, and Dalbergia latifolia.

Tileswornath CF was selected because it is managed under ScFM with a sufficient number of Shorea robusta trees containing hollows. This CF just carried out the felling of trees that were required for this study.
2.2. Data Collection and Measurement. The data were collected from the first annual coupe of regeneration felling block C1S8 of the CF. Simple random sampling was used to select the tree and the destructive method was used for measurement of hollowness in the regeneration annual coupe. A total of 44 trees of Shorea robusta were sampled to study hollowness and for the stumpage analysis entire C1S8 block was enumerated.

Before felling of a tree, $\mathrm{DBH}$, girth, and height were measured. Logs of $2.5 \mathrm{~m}$ in length were prepared after the felling of a tree. After the sectioning of the felled tree, hollowed and nonhollowed logs were separated. For the nonhollowed solid log, mid-diameter and length were measured. For the hollowed log, mid-diameter and hollowness diameter are measured at the thick end and thin end for each log. On each end of a hollow log, the hollowness diameter was measured on the widest $(D 1)$ and narrowest (D2) part on each end of the log. D1 and D2 for each end were averaged to obtain the average hollowness diameter at each end of the $\log$ (Figure 2).

Length of the hollowness was measured using measuring tape. During the data collection, the stump height and girth were measured. GPS points of the stumps were taken and whole block C1S8 was enumerated.

2.3. Analysis. Logs shape was assumed as cylindrical shape so that the total volume of all the logs was calculated using the formula for the estimation of the volume of a cylinder (Equation I). For the log which has hollow, the cross-sectional areas of the hollow part of both the thick end (Equation II) and thin end (Equation III) were measured. The volume of hollowness was obtained by using Smalian's formula (Equation IV) [12]. After finding the total volume and hollow volume, actual volume was calculated by subtracting hollowness volume from total volume (Equation $\mathrm{V}$ ) (Table 1).

Logistic regression analysis was carried to find out the relationship of hollowness presence, diameter, and total height by preparing three models.

(1) Hollowness $=a+b *$ total height $(\mathrm{m})$, Model 1

(2) Hollowness $=a+b *$ diameter $(\mathrm{cm})$, Model 2

(3) Hollowness $=a+b *$ diameter $(\mathrm{cm})+c *$ total height (m), Model 3

Here $a, b$, and $c$ denote coefficients, $m$ denotes meter, and $\mathrm{cm}$ denotes centimeter.

These three models were compared, and the best-fitted model was selected based on the selection parameter. Different packages of $R$ Statistics were used to perform logistic regression analysis and model selection.

\section{Results}

A total of 44 trees of Shorea robusta were sampled, sectioned, and measured, in which 26 trees (59\%) were found with hollow and only 18 trees (41\%) were found free from hollow (Figure 3(a)). Out of a total 285 logs, 98 logs (34.39\%) were 


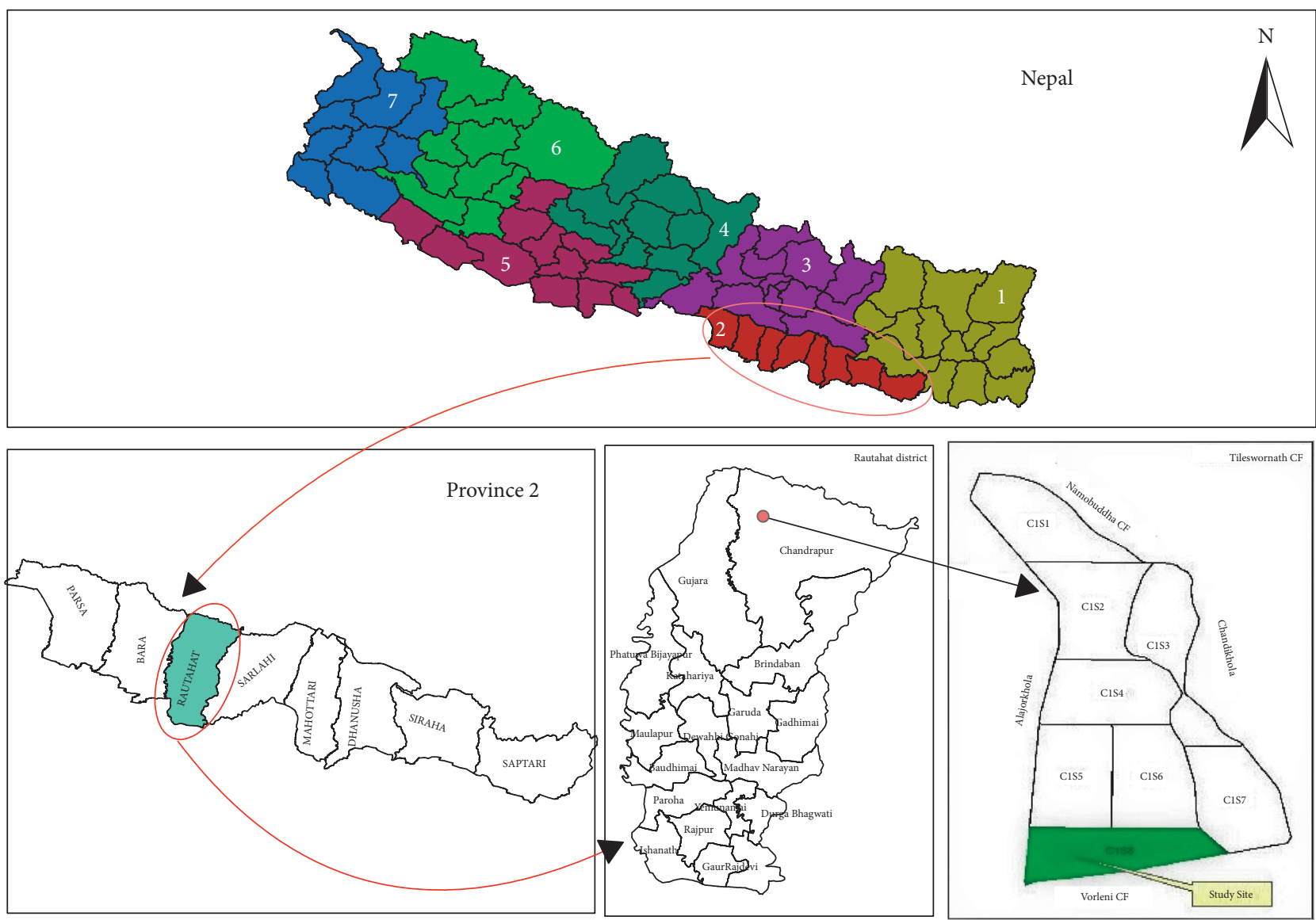

FIGURE 1: Study area map showing subcompartment, CF, district, province of Nepal.

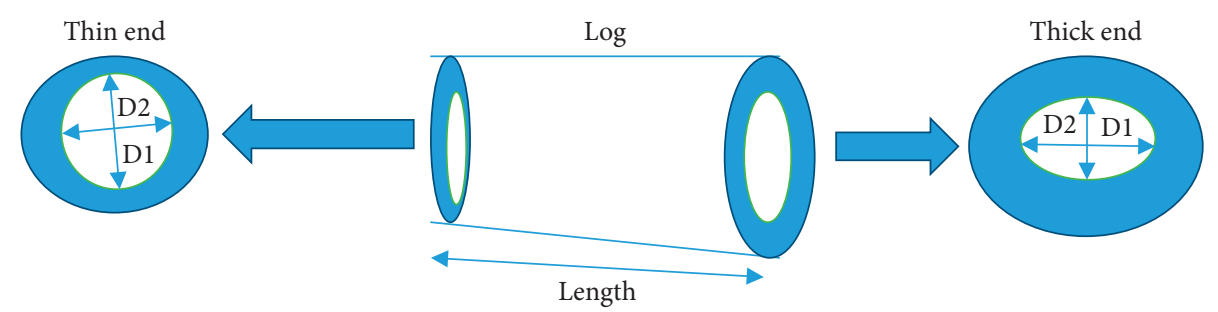

Figure 2: Illustration of log length and cross section of log with hollowness and measurement.

found with hollow, and the remaining 187 logs (65.61\%) were found free from hollow (Figure 3(b)).

The total volume of the sampled logs was $101.38 \mathrm{~m}^{3}$, whereas the total volume of nonhollow logs was $42.60 \mathrm{~m}^{3}$ and that of hollowed logs was $58.78 \mathrm{~m}^{3}$ (Figure 4 ). The volume of the hollow portion was calculated as $24.57 \mathrm{~m}^{3}$; that is, $24.23 \%$ of the total volume was occupied by sample tree and $41.79 \%$ of the volume was occupied by hollow log volume.

3.1. Total Height and Hollow Length of Shorea robusta. The height range of Shorea robusta was found to be from $7 \mathrm{~m}$ to $32 \mathrm{~m}$ but most of the tree had a height between first quartile $14 \mathrm{~m}$ to third quartile $22 \mathrm{~m}$ with a median of $18 \mathrm{~m}$. The mean height of Shorea robusta was found to be $17.5 \mathrm{~m}$ (Figure 5(a)). Hollow length in Shorea robusta was found to be ranging from $2.5 \mathrm{~m}$ to $17 \mathrm{~m}$. The mean hollow length of Shorea robusta was found to be $7.5 \mathrm{~m}$ (Figure 5(b)).

3.2. Relationship of Hollow Tree with Tree Diameter and Height. A tree with a larger diameter was found to be highly affected by the hollowness, whereas a less diameter tree was found to be free from hollow (Figure 6(a)). In comparing hollow with the tree height, it is indicated that the tree with larger height has been mostly found with hollow, and trees with lesser height have been mostly found with solid trunk (Figure 6(b)).

Statistically, logistic regression analysis was performed to finalize the result obtained from visual analysis. By analysis fitted criteria AIC, AICc, and BIC, Model. 2 was found to be best fitted as Model. 2 has a low value of Akaike Information Criterion (AIC), corrected version of Akaike Information 
TABle 1: Equation for calculating the total volume, hollowness, and actual volume of logs.

\begin{tabular}{|c|c|c|c|}
\hline Equation for calculating different parameter & $\begin{array}{c}\text { Equation } \\
\text { number }\end{array}$ & Basis of equation & Remarks \\
\hline Volume of $\log =\left(3.14 * d^{2} / 4\right) * L$ & Equation (I) & Cylindrical formula & $\begin{array}{c}d=\text { mid-diameter of the } \log \\
L=\text { length of the } \log \end{array}$ \\
\hline $\begin{array}{l}\text { Cross-sectional area of the thick end of } \log S 1= \\
\left.((D 1+D 2) / 2)^{2} / 4\right) * L\end{array}$ & Equation (II) & $\begin{array}{l}\text { Area of cross section of } \\
\text { cylinder }\end{array}$ & $\begin{array}{c}D 1=\text { longest diameter of hollow at } \\
\text { thick end } \\
D 2=\text { shortest diameter of hollow at } \\
\text { thick end } \\
L=\text { length of the log }\end{array}$ \\
\hline $\begin{array}{l}\text { Cross-sectional area of the thin end of } \log S 2= \\
\left.((D 1+D 2) / 2)^{2} / 4\right) * L\end{array}$ & Equation (III) & $\begin{array}{l}\text { Area of cross section } \\
\text { formula }\end{array}$ & $\begin{array}{c}D 1=\text { longest diameter of hollow at } \\
\text { thin end } \\
D 2=\text { shortest diameter of hollow at } \\
\text { thin end } \\
L=\text { length of the log }\end{array}$ \\
\hline Hollowness volume $=((S 1+\underline{S} 2) / 2) * L$ & Equation (IV) & Smalian's formula & $\begin{array}{l}S 1=\text { cross section of the thick end of } \\
\log \\
S 2=\text { cross section of the thin end of } \\
\log \\
L=\text { length of the } \log \end{array}$ \\
\hline $\begin{array}{l}\text { Volume of actual timber = Equation }(\mathrm{I})-\text { Equation } \\
(\mathrm{IV})\end{array}$ & Equation $(\mathrm{V})$ & Subtraction & $L=$ length or the log \\
\hline
\end{tabular}

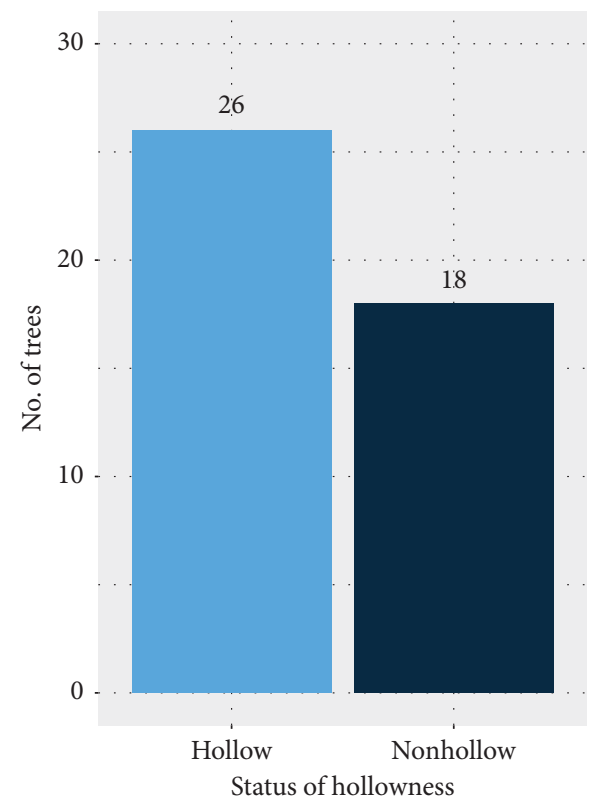

(a)

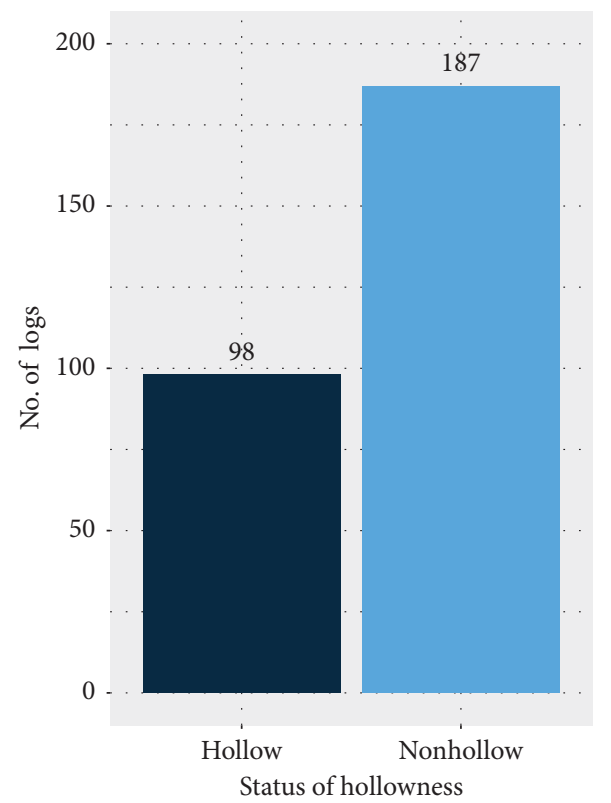

(b)

Figure 3: (a) Status of hollowed tree. (b) Status of hollowed log.

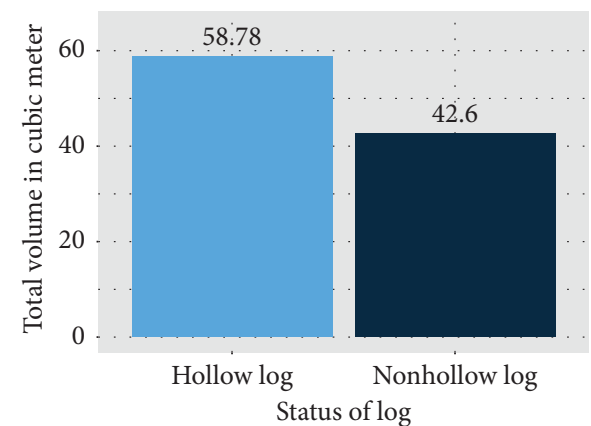

FIgURE 4: Total volume in a cubic meter of hollow and nonhollow log. 


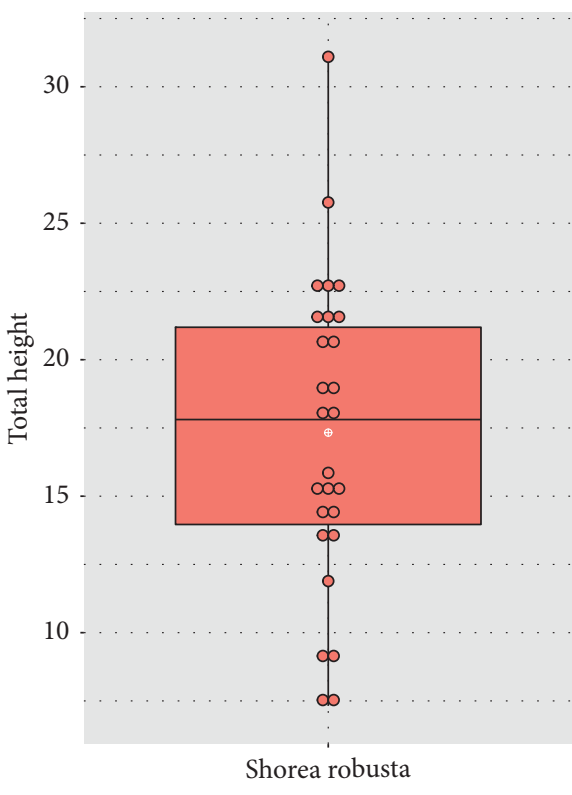

(a)

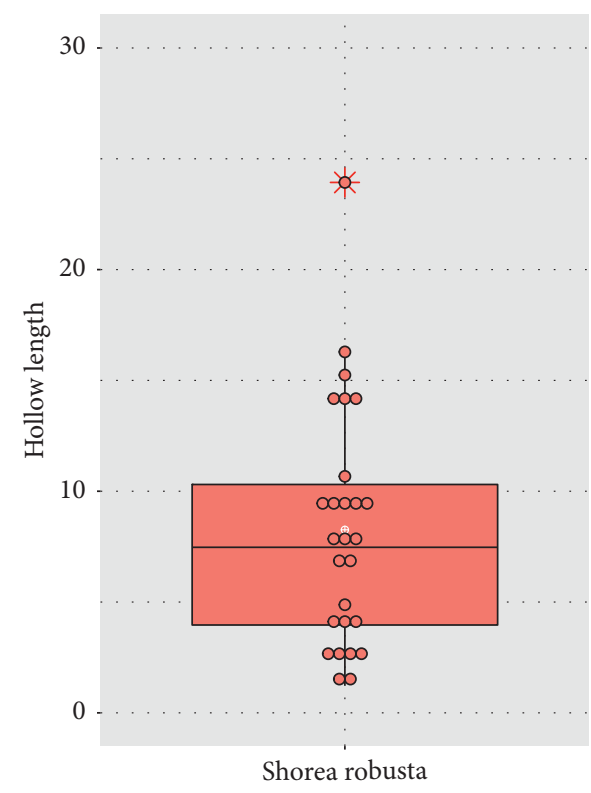

(b)

FIgURe 5: (a) Variation in height of Shorea robusta. (b) Hollow length variation of Shorea robusta.

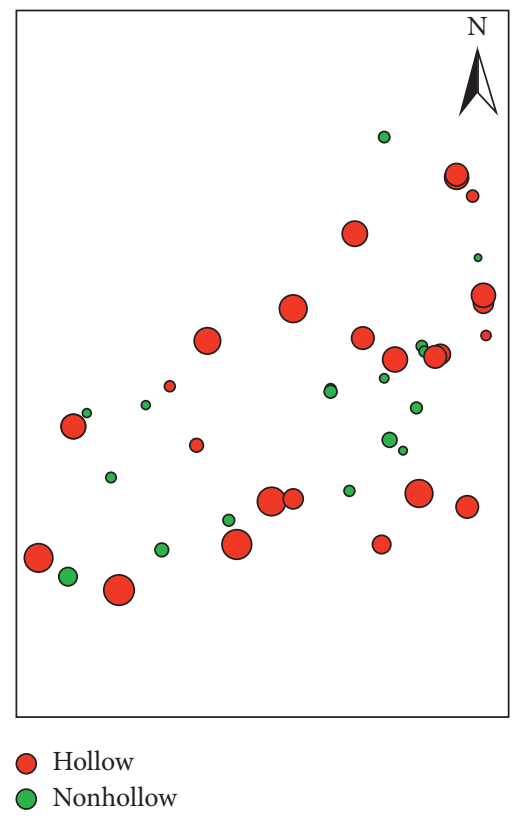

(a)

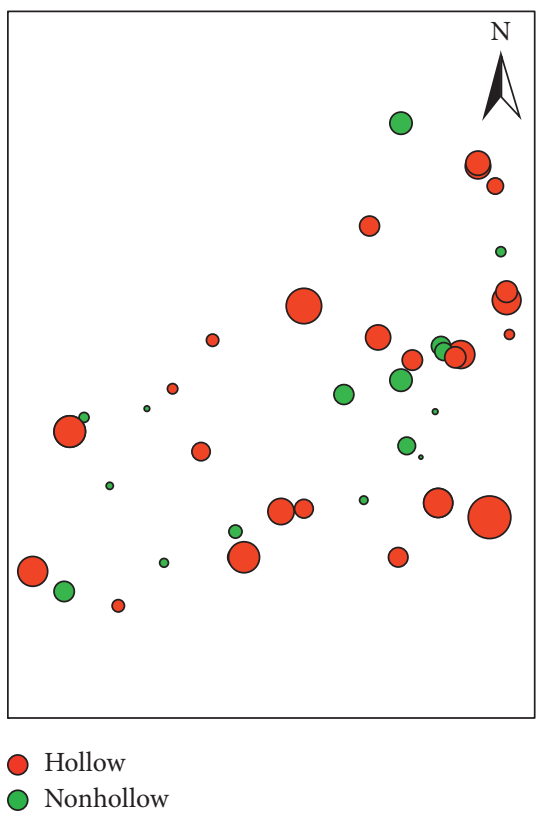

(b)

FIGURE 6: (a) Spatial distribution and relationship of hollowness with tree diameter (size of the circle indicates the size of tree diameter). (b) Relationship of hollowness with tree height (size of the circle indicates the size of tree height).

Criterion (AICc), and Bayesian Information Criterion (BIC) in comparison to Model.1 and Model.3 (Table 2). Further, pseudo- $R$-square was observed through McFadden, Cox and Snell, and Nagelkerke's method. As the value of McFadden, Cox and Snell, and Nagelkerke's method was low for Model.1 in comparison to other models, values were equal for Model. 2 and Model.3 so that Model.1 and Model.3 were rejected.

The expression for the best fitted Model 2 is as follows: hollowness presence $=-6.14+0.14 * \operatorname{diameter}(\mathrm{cm})$.
Also, the logistic model of the probability of hollowness through the diameter of the tree (Model.2) was plotted which expressed the range of hollowness absent to hollowness present diameter with logistic line (Figure 7).

3.3. Timber Volume Remained in the Stump. The distributional map of the stump in the block C1S8 of the CF before ScFM was in practice is shown below in the map (Figure 8). 
TABLE 2: Coefficients, selection parameters, and results for the logistic regression.

\begin{tabular}{lcccccccccc}
\hline \multirow{2}{*}{ Model } & \multirow{2}{*}{ Independent variable } & \multicolumn{3}{c}{ Coefficients } & \multirow{2}{*}{ AIC } & \multirow{2}{*}{ AICc } & BIC & \multicolumn{4}{c}{ Pseudo- $R$-square value } \\
& & A & $\mathrm{b}$ & $\mathrm{c}$ & & & & McFadden & Cox and Snell & Nagelkerke's method \\
\hline Model.1 & Height $(\mathrm{m})$ & -2.73 & 0.22 & - & 51.56 & 52.16 & 56.92 & 0.23 & 0.27 & 0.36 \\
Model.2 & Diameter $(\mathrm{cm})$ & -6.14 & 0.14 & - & 32.84 & 33.44 & 38.19 & 0.54 & 0.52 & 0.70 \\
Model.3 & Diameter $(\mathrm{cm})$ and height $(\mathrm{m})$ & -6.21 & 0.14 & 0.02 & 34.80 & 35.83 & 41.94 & 0.54 & 0.52 & 0.70 \\
\hline
\end{tabular}

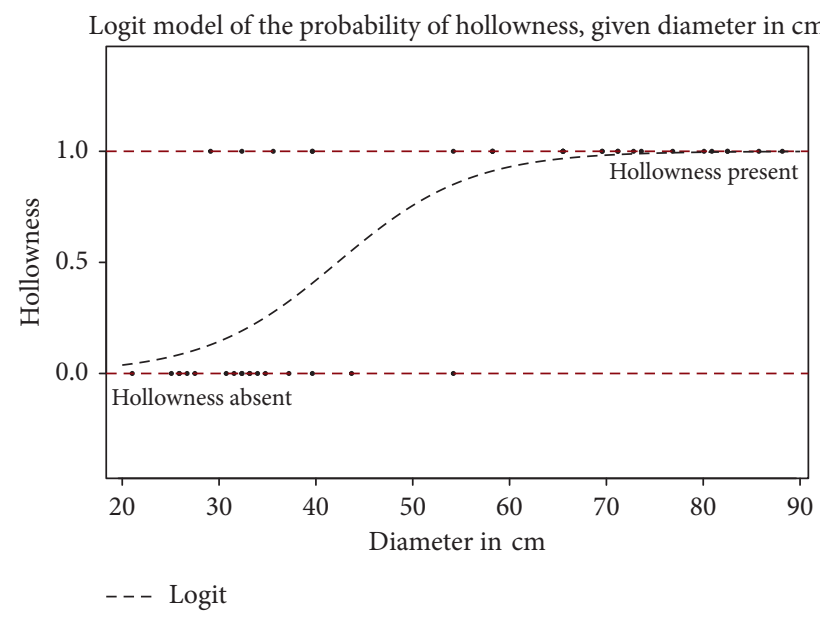

FiguRE 7: Logistic model curve of the probability of hollowness.

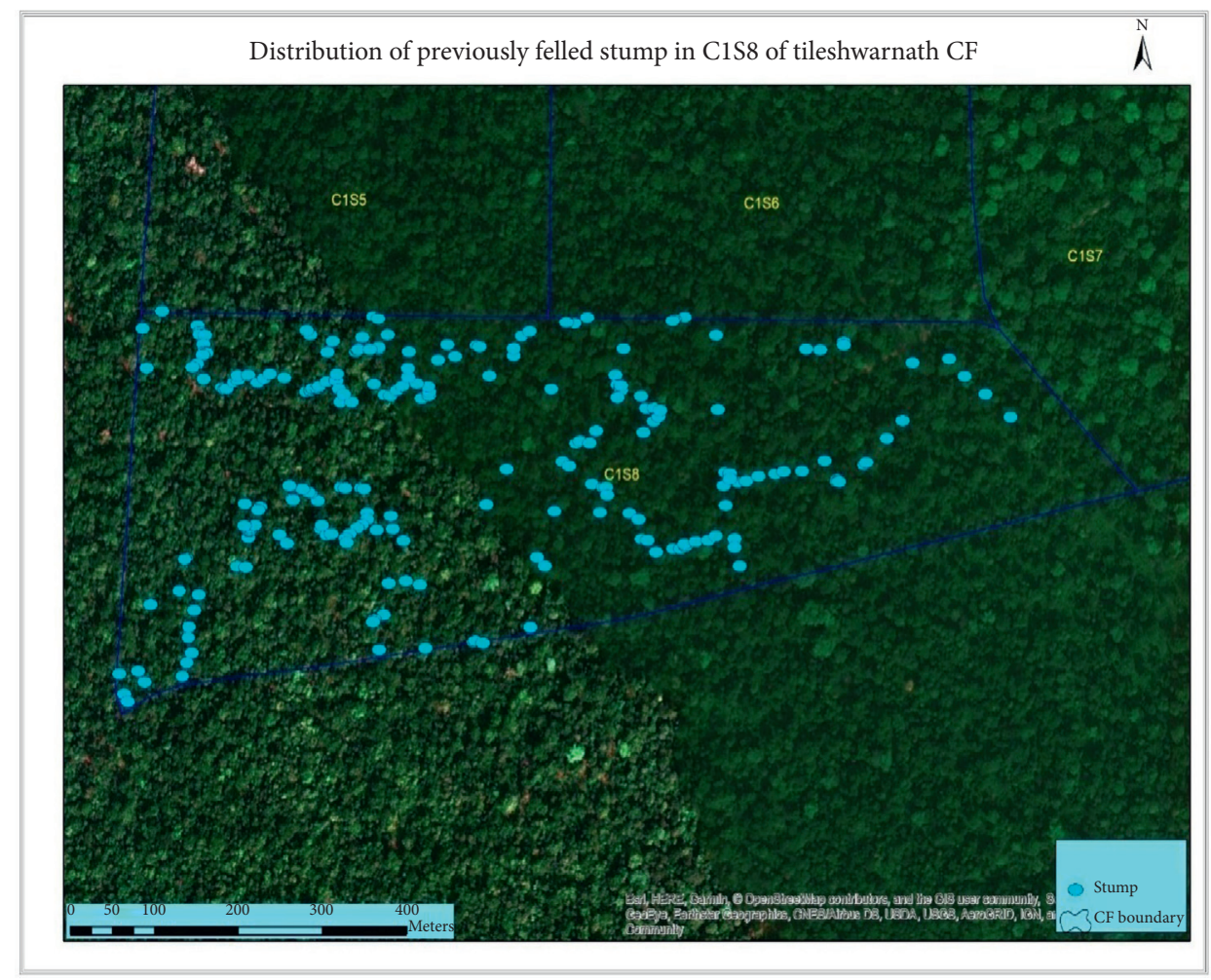

FIGURE 8: Distribution map of the old stumps.

Out of 226 stumps of the block which was there before the implementation of scientific forest management, C1S8 which occupies 26.3 ha area, almost all stumps were more than 1 foot. All the data of stump height and girth of the timber were computed to find out the timber volume retained in the stump edge. 


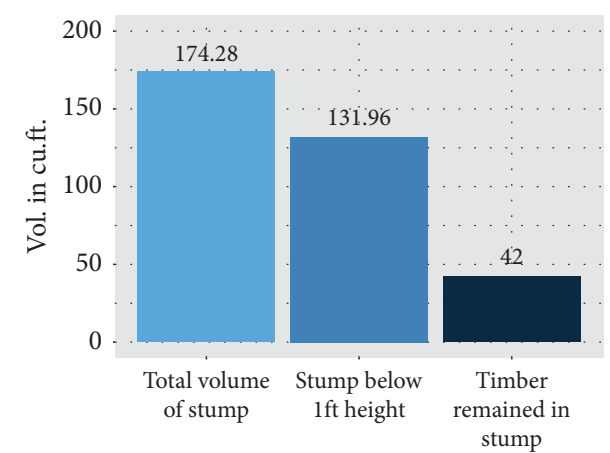

FIGURE 9: Volume of timber remaining in old stumps.

A total volume of 226 stumps was found to be 174.28 cubic feet. Stump below $1 \mathrm{ft}$. height was 131.96 feet. Timber remaining in stump edge was 42.32 cubic feet (Figure 9).

Shorea robusta was severely affected by the heart rot causing fungi in Nepal and became a serious problem as timber is one of the valuable timbers in the country [13-15]. The serious economic loss was caused by heart rot [16]. The study conducted in Chitwan National Park by [17] has concluded that the maximum number of cavities was found on Shorea robusta and it found a positive relationship between tree size and cavities. The research carried out in the past highlighted that heart rot is a major problem, though few studies were conducted on the loss assessment by the heart rot and its relation to the diameter and height of the Shorea robusta in India and Nepal.

$\mathrm{ScFM}$ is blamed to harvest green trees and controversy arose during the implementation of the program due to the high number of trees cut in comparison to passive management followed during the past; but actually it was found that ScFM helps to remove overmature, diseased, and decayed trees from the forest and helps to maintain the forest's health [18]. Heart rot can be very hard to prevent and control but can be avoided if a tree is carefully monitored over its entire lifetime [19] and the active management scheme of ScFM enhances the monitoring activities in comparison to passive management. The sustainable practice of harvesting can enhance forest's health and also maximize the benefit by reducing the overmature trees [20]. This study also found harvested tree with larger diameter which are ultimately of old age has higher occurrence of heart rot in comparison to tree with smaller diameter. So the results highlighted the need for reducing rotation period and proper attention during pruning, fire, and grazing as heart rot causing fungi can be introduced due to these activities. The importance of ScFM in the productive and effective management of forests is also reinforced.

\section{Conclusions and Recommendations}

About $59 \%$ of the sample trees and $34.39 \%$ of the total number of the logs were found to be affected by the hollowness. $41.79 \%$ volume was lost due to the hollow in the hollowed tree. The average height of the sample tree was found to be $17.5 \mathrm{~m}$ and the average hollow length was found to be $7.5 \mathrm{~m}$. From the visual analysis, it was indicated that diameter and total height have some relation with hollowness presence, but logistic regression discards the relation with the total height on the probability of hollowness presence. So, it was concluded that the diameter size indicates the probability of hollowness. The timber retained in the stump per tree was found to be 0.29 cubic feet in the forest before the implementation of ScFM. If ScFM was implemented before, this volume of timber would not have been lost.

Accounting of defects in wood must be done to avoid overestimation of timber volume. For estimation of timber volume, defect volume should be seriously taken into consideration to get actual timber volume. Hollowness in wood is seen as a major problem; proper practices to reduce it should be identified and applied, and care should be given to the plants right from the regeneration stage.

\section{Data Availability}

The data used to support the findings of this study are available from the corresponding author upon request.

\section{Conflicts of Interest}

The authors declare no conflicts of interest.

\section{Acknowledgments}

The authors are grateful to the District Forest Office Rautahat for coordination during the harvesting time, due to which the data collection was possible, Tileshower Community Forest User Group for the support during the data collection, and Faculty of Forestry for providing equipment for the measurement.

\section{References}

[1] W. C. Shortle and K. R. Dudzik, Wood Decay in Living and Dead Trees: A Pictorial Overview. Gen. Tech Rep. NRS-97, p. 26, U.S. Department of Agriculture, Forest Service, Northern Research Station., Newtown Square, PA, USA, 2012.

[2] A. Rimbawanto and C. Beadle, "Heart rot and root rot in tropical Acacia plantations," in Proceedings of a Workshop, Yogyakarta, Indonesia, February 2006.

[3] K. T. Smith and W. C. Shortle, A First Look at Tree Decay. An Introduction to How Injury and Decay Affect Trees, Na-Pr-0298 https://www.nrs.fs.fed.us/pubs/8548, 1998.

[4] P. E. Hennon and R. L. Mulvey: Managing heart rot in live trees for wildlife habitat in young-growth forests of Coastal Alaska. General Technical Report PNW-GTR-890. Portland, OR: US Department of Agriculture, Forest Service, Pacific Northwest Research Station, 2014.

[5] E. L. Webb and R. N. Sah, "Structure and diversity of natural and managed sal (Shorea robusta Gaertn.f.) forest in the Terai of Nepal," Forest Ecology and Management, vol. 176, no. 1-3, pp. 337-353, 2003.

[6] K. Kanel, K. Shrestha, A. Tuladhar, and M. Regmi: A study on the demand and supply of wood products in different regions of Nepal. Kathmandu: REDD-Forestry Climate Change Cell Babarmahal, 2012. 
[7] B. S. Aryal, S. R. Joshi, and A. J. Shrestha, Building Timber Value Chains for REDD+ in Nepal, ICIMOD Working Paper 2016/9 https://lib.icimod.org/record/32385, 2016.

[8] B. Budha, M. Panta, and R. A. Mandal, "Economic loss caused by hollow and shake defects in log, Nepal," Turkish Journal of Agriculture and Forestry, vol. 2, no. 2, pp. 114-121, 2018.

[9] R. L. Goldingay, "Characteristics of tree hollows used by Australian birds and bats," Wildlife Research, vol. 36, no. 5, p. 394, 2009.

[10] P. Gibbons and D. Lindenmayer, Tree Hollows and Wildlife Conservation in Australia, CSIRO Publishing, Clangton, Australia, 2019.

[11] L. S. Khanna, Forest Protection, 5th edition, 2010.

[12] Ministry of Forests Lands and Natural Resource Opperations, "Scaling manual," in Ministry of Forests Lands and Natural Resource Opperations, https://www.for.gov.bc.ca/ftp/hva/ external/!publish/web/manuals/Scaling/2011/ Scaling2011NovMaster.pdf, 2011.

[13] R. Acharya and G. Parmar, "Preliminary documentation of basidiomycetous fungi (polypores and mushrooms) found in bardia national Park and its buffer zone area, western Nepal," in Plant Resource: A Scientific Publication, vol. 38, pp. 22-29, , no. 1, Department of Plant Resource Nepal, Nepal, 2016.

[14] H. Aryal and U. Budathoki, "Ethnomycological studies on some macro-fungi in Rupandehi District, Nepal," Banko Janakari, vol. 23, no. 1, pp. 51-56, 2013.

[15] S. K. Jha and N. N. Tripathi, "Diversity of macrofungi in shivapuri national Park of kathmandu valley, Nepal," Biological Forum - An International Journal, vol. 4, no. 1, pp. 27-34, 2012.

[16] B. K. Bakshi, "Heart-rots in relation to management of sal," Indian Forester, vol. 83, no. 11, pp. 651-661, 1957, http://www. indianforester.co.in/index.php/indianforester/article/view/ 24303.

[17] P. Bhusal, D. Czeszczewik, W. Walankiewicz et al., "Availability of tree cavities in a sal forest of Nepal," IForest, vol. 9, no. APR2016, pp. 217-225, 2016.

[18] P. Shahi, Scientific Forestry. The Kathmandu Post, https:// kathmandupost.com/opinion/2016/04/03/scientific-forestry, 2016.

[19] S. K. Jha, "Identification and management of heart-rot fungi," Banko Janakari, vol. 30, no. 2, pp. 71-77, 2020.

[20] D. B. Lindenmayer, J. F. Franklin, A. Lõhmus et al., "A major shift to the retention approach for forestry can help resolve some global forest sustainability issues," Conservation Letters, vol. 5, no. 6, pp. 421-431, 2012. 